\title{
Evapotranspiration, biomass production and water productivity acquired from Landsat 8 images in the northwestern side of the São Paulo state, Brazil
}

Antônio H. de C. Teixeira, Janice F. Leivas, Fernando B. T. Hernandez, Renato A. M. Franco, Daniel N. C. Nuñez

Antônio H. de C. Teixeira, Janice F. Leivas, Fernando B. T. Hernandez, Renato A. M. Franco, Daniel N. C. Nuñez, "Evapotranspiration, biomass production and water productivity acquired from Landsat 8 images in the northwestern side of the São Paulo state, Brazil," Proc. SPIE 9998, Remote Sensing for Agriculture, Ecosystems, and Hydrology XVIII, 99981D (25 October 2016); doi: 10.1117/12.2241625

SPIE. Event: SPIE Remote Sensing, 2016, Edinburgh, United Kingdom 


\title{
Evapotranspiration, biomass production and water productivity acquired from Landsat 8 images in the northwestern side of the São Paulo state, Brazil
}

\author{
Antônio H. de C. Teixeira*a ; Janice F. Leivas ${ }^{\mathrm{a}}$; Fernando B. T. Hernandez ${ }^{\mathrm{b}}$; Renato A. M. Franco ${ }^{\mathrm{b}}$; \\ Daniel N. C. Nuñez \\ ${ }^{a}$ Embrapa Satellite Monitoring - CEP - 13070-115 - Campinas - SP, Brasil \\ ${ }^{\text {b}}$ São Paulo State University- CEP - 13083-886 - Ilha Solteira - SP, Brasil
}

\begin{abstract}
.
In the northwestern side of the São Paulo state, Brazil, irrigated areas are expanding, because rainfall is not enough to supply the crop water requirements. Under the actual climate and land-use change scenarios, large-scale evapotranspiration (ET) and biomass production (BIO) acquirements are relevant. Eleven Landsat 8 images, from May 2013 to October 2014, were used together with a net of eight agrometeorological stations for modelling these water productivity (WP) parameters in the main agricultural growing irrigated areas inside three hydrological basins in this region. Some of these areas inside of each basin were highlighted for more in-depth WP analyses. The SAFER algorithm estimated the ratio of actual (ET) to reference (ET0) evapotranspiration and this ratio was used for both, to calculate ET and to include the soil moisture effects in the Monteith's Radiation Use Efficiency (RUE) model. The highlighted agricultural growing regions were Paranapuã, Populina and Santa Rita d'Oeste in the Turvo/Grande basin; Rubinéia, Santa Fé do Sul, Suzanópolis and Ilha Solteira, in the São José dos Dourados basin; and Pereira Barreto and Sud Mennucci, in the Baixo Tietê basin. The highest averages of both ET $\left(1.7 \pm 0.9 \mathrm{~mm} \mathrm{~d}^{-1}\right)$ and BIO $\left(47 \pm 31 \mathrm{~kg} \mathrm{ha}^{-1} \mathrm{~d}^{-1}\right)$ were for Ilha Solteira, while the lowest ones happened in Sud Mennucci $\left(1.3 \pm 0.7 \mathrm{~mm} \mathrm{~d}^{-1}\right.$ and $\left.40 \pm 27\right)$. These ET and BIO ranges returned WP values varying from $2.2 \pm 0.6$ to $2.6 \pm 0.8 \mathrm{~kg} \mathrm{~m}^{-3}$, with the higher end of this range happening in the Turvo/Grande hydrological basin. Considering the annual time-scale, crops will consume around 770, 828 and 786 $\mathrm{mm} \mathrm{yr}^{-1}$ with the corresponding BIO values of 27, 26 and $25 \mathrm{t} \mathrm{ha}^{-1} \mathrm{yr}^{-1}$, respectively in Turvo/Grande, São José do Dourados and Baixo Tietê. It was concluded that increments in agricultural irrigated areas should be stimulated in the northwestern side of the state, mainly in the first basin, to retrieve good yield with less water use.
\end{abstract}

Key-words: land-use changes, irrigation, water resources, SAFER.

\section{INTRODUCTION}

In the northeastern side of the São Paulo state, Brazil, irrigated areas have been replacing natural vegetation, throughout water use at the vicinities of the hydrological basins of Turvo/Grande (TG), São José dos Dourados (SJD) and Baixo Tietê (BT). The main crops are sugar cane, citrus, grains, fruits and rubber trees. The expansion of these crops is raising the large-scale water demand and with probabilities of natural water scarcity, irrigation is an essential practice for crop development ${ }^{1}$.

Considering these climate and land-use changes, it is important to apply tools for quantifying water productivity parameters analysing their dynamics inside the hydrological basins for supporting policy planning and decision makings about the water resources. For this task, one needs to quantify evapotranspiration (ET) and biomass production (BIO) to obtain the water productivity (WP), which in the current research, is considered as the ratio of BIO to ET. Remote sensing together with Geographic Information Systems (GIS), excludes the need of quantifying complex large-scale hydrological

*heriberto.teixeira@embrapa.br; Phone 5519 3211-6200; Fax: 5519 3211-6222; www.cnpm.embrapa.br

Remote Sensing for Agriculture, Ecosystems, and Hydrology XVIII, edited by

Christopher M. U. Neale, Antonino Maltese, Proc. of SPIE Vol. 9998, 99981D

(C) 2016 SPIE · CCC code: 0277-786X/16/\$18 - doi: 10.1117/12.2241625

Proc. of SPIE Vol. 9998 99981D-1 
processes, being suitable for determining and mapping the spatial and temporal structures of ET on large scales. The use of satellite images and GIS to acquire ET from different agro-ecosystems has been carried out in distinct climate regions $^{2-4}$.

The SAFER (Simple Algorithm For Evapotranspiration Retrieving) algorithm for retrieving ET was developed and validated with field data and Landsat images applied to irrigated crops and natural vegetation under strong thermohydrological contrasts, in Brazil ${ }^{5-6}$. In the current research, it is used together with a net of agrometeorological stations and the Monteith's Radiation Use Efficiency (RUE) model for WP assessments ${ }^{7}$.

BIO is a key indicator for any ecosystem, and its values are highly variable in both space and time ${ }^{8}$. In water-limited environments, the challenge is the BIO improvements through optimized management practices ${ }^{7,-10}$. For its estimations, the RUE concept based in solar radiation interception is applied in the current research ${ }^{11}$, being the degree of this interception variable along the year and crop stages ${ }^{7,12}$. Although uncertainties arising in connection with RUE values in in mixed agro-ecosystems, due to their spatiotemporal variations ${ }^{13}$ and moisture conditions ${ }^{9}$, the model accuracy has been considered acceptable for large-scale applications with satellite data.

Images from MODIS satellite, combined precipitation, temperature and elevation data have been used for mapping forest BIO values in California ${ }^{14}$. MODIS images were also used in Guandong, China, to evaluate the feasibility of setting up new biomass power plants and to optimize the locations of plants ${ }^{15}$. In Brazil, BIO estimations have been made in mixture of agro-ecosystems from distinct regions. The Monteith's RUE model can be used together with any satellite data for quantifying the spatial and temporal variation of BIO in composite landscapes ${ }^{4,7,16}$.

The satellite Landsat 8 was launched on February 11, 2013 and normal operations started on May 30, 2013. The Operational Land Imager (OLI) on this satellite is a nine-band push broom scanner with a swath width of $185 \mathrm{~km}^{17}$. Despite some water productivity studies have been carried out in Brazil with satellites having different spatial and temporal resolutions, new researches are needed for applications of Landsat 8 to evaluate ET and BIO, especially for operational water productivity monitoring in mixed agro-ecosystems under rapid land-use changes and having large thermohydrological variations.

The objective of this paper is to combine Monteith's RUE model and the SAFER algorithm to demonstrate that when these models are applied to Landsat 8 satellites and agro-meteorological data, they are useful for environmental monitoring. The applications aimed water productivity assessments in the mixed agro-ecosystems containing irrigated crops and natural vegetation under the conditions of climate and land-use changes of the hydrological basins in the northwestern side of São Paulo state, Brazil.

\section{MATERIAL AND METHODS}

\subsection{Hydrological basins, study area and data set}

Fig. 1 shows the location of the hydrological basins of Turvo/Grande, São José dos Dourados e Baixo Tietê in the northwestern side of the São Paulo state, Southeast Brazil, together with the limits of the agricultural growing areas and the net of agrometeorological stations used for the weather data interpolation processes. 


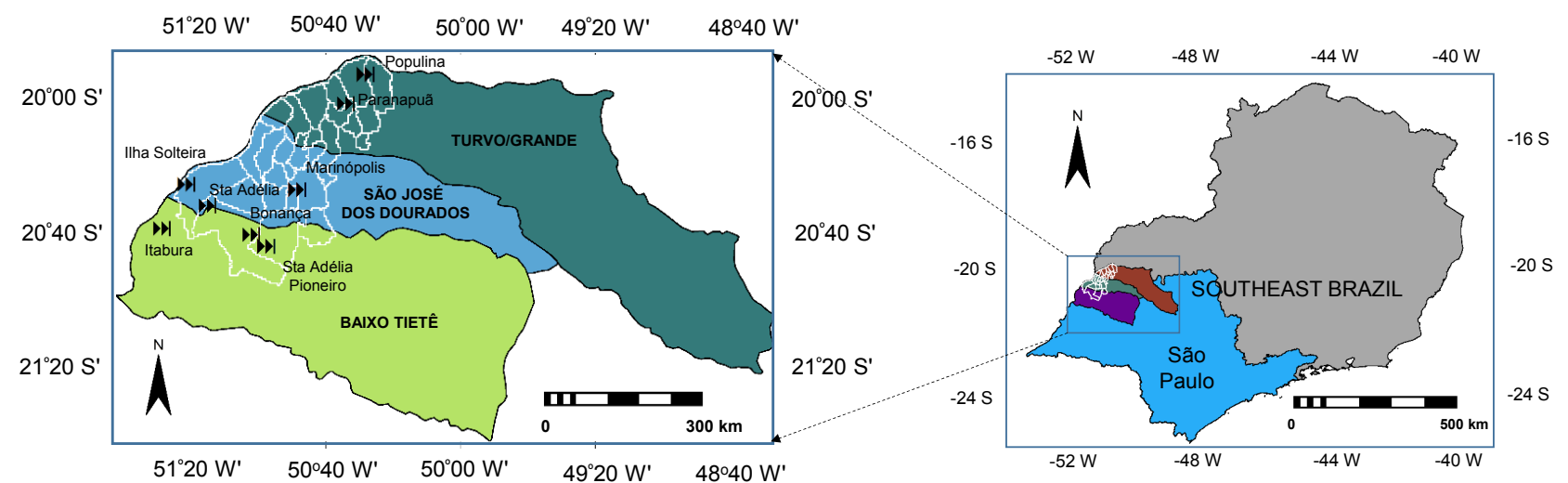

Figure 1. Location of hydrological basins of Turvo/Grande, São José dos Dourados e Baixo Tietê in the northwester side of the São Paulo state, Southeast Brazil, together with the limits of agricultural growing areas and the net of agrometeorological stations used for the weather data interpolation processes.

The study area is characterized by a dry winter and a moderate and wet summer, presenting the highest ET rates of the State. Some periods with absence of rains may limit crop production without irrigation due to the natural water deficits, which can occur at durations as long as eight months ${ }^{18}$.

Eleven Landsat 8 images from May 2013 to October 2014 were used, together with eight agrometeorological stations from the São Paulo University State - UNESP. The images were acquired on 01 May 2013 (Day 121); 04 July 2013 (Day 185); 21 August 2013 (Day 233); 06 September 2013 (Day 252); 27 December 2013 (Day 361); 28 January 2014 (Day 028); 02 April 2014 (Day 092); 23 July 2014 (Day 204); 08 August 2014 (Day 220); 24 August 2014 (Day 236); and 11 October 2014 (Day 284). Global solar radiation (RG), air temperature $\left(\mathrm{T}_{\mathrm{a}}\right)$, relative humidity $(\mathrm{RH})$ and wind speed $(\mathrm{u})$ were taken to calculate reference evapotranspiration $(\mathrm{ET0})$ by the Penman-Monteith method ${ }^{19}$. During the modeling steps, RG, $T_{a}$ and ET0 were used at daily time-scale and interpolated by using the moving average method creating grids with the same spatial resolution as the satellite images.

\subsection{Large-scale water productivity modelling}

For each Landsat 8 image, the spectral radiances $\left(\mathrm{L}_{\mathrm{b}}\right)$ were computed from Digital Numbers $(\mathrm{DN})$ :

$\mathrm{L}_{\mathrm{b}}=$ Gain $\mathrm{x} \mathrm{DN}+$ Offset

where Gain and Offset refer to the values given in the metadata file ${ }^{17}$.

The planetary albedo for each Landsat satellite band $\left(\alpha p_{b}\right)$ was calculated as:

$\alpha \mathrm{p}_{\mathrm{b}}=\frac{\mathrm{L}_{\mathrm{b}} \pi \mathrm{d}^{2}}{\mathrm{Ra}_{\mathrm{b}} \cos \varphi}$

where $L_{b}$ is the spectral radiance for the wavelengths of band $b\left(\mathrm{~W} \mathrm{~m}^{-2} \mathrm{sr}^{-1} \mu \mathrm{m}^{-1}\right), d$ is the relative earth-sun distance; $\mathrm{Ra}_{\mathrm{b}}$ is the mean solar irradiance at the top of the atmosphere (or atmospheric irradiance) for each band $\left(\mathrm{W} \mathrm{m}^{-2} \mu \mathrm{m}^{-1}\right)$ and $\varphi$ the solar zenith angle

$\mathrm{Ra}_{\mathrm{b}}$ for each of the bands 1 to 7 of the L8 sensor was calculated according to the Planck's low, integrating the radiation over the wavelength intervals and considering its fraction over the solar spectrum, assuming the sun as a blackbody. Then, the broadband planetary albedo $\left(\alpha_{\mathrm{p}}\right)$ was calculated as the total sum of the different narrow-band $\alpha \mathrm{p}_{\mathrm{b}}$ values according to the weights for each band $\left(\mathrm{w}_{\mathrm{b}}\right)$.

$\alpha p=\sum w_{b} \alpha p_{b}$

where the $\mathrm{w}_{\mathrm{b}}$ values were computed as the ratio of the amount of the incoming shortwave radiation from the sun at the top of the atmosphere in a particular band and the sum for all the bands ${ }^{20}$. 
The spectral radiances from the bands $10\left(\mathrm{~L}_{10}\right)$ and $11\left(\mathrm{~L}_{11}\right)$ from the thermal regions were converted into radiometric temperatures applicable at the top of the atmosphere $\left(\mathrm{T}_{\mathrm{b}}\right)$ by inversion of the Plank's law in the 10.6-11.19 $\mu \mathrm{m}$ (band 10) and 11.5-12.51 $\mu \mathrm{m}$ (band 11) bandwidth:

$$
\mathrm{T}_{\mathrm{b}}=\frac{\mathrm{K}_{2}}{\ln \left(\frac{\mathrm{K}_{1}}{\mathrm{~L}_{\mathrm{b}}+1}\right)}
$$

where $\mathrm{K}_{1}$ (774.89 and 480.89) and $\mathrm{K}_{2}$ (1321.08 and 1201.14) for bands 10 and 11, respectively, are conversion coefficients for the L8 satellite. The average $\mathrm{T}_{\mathrm{b}}$ value from the two bands was considered the brightness temperature $\left(\mathrm{T}_{\text {bright }}\right)^{20}$.

The results for both $\alpha_{\mathrm{p}}$ and $\mathrm{T}_{\text {bright }}$ were corrected atmospherically for acquiring the albedo $\left(\alpha_{0}\right)$ and temperature $\left(\mathrm{T}_{0}\right)$ surface values, by regression equations obtained from satellite and field measurements in the Brazilian semi-arid region?

The Normalized Difference Vegetation Index (NDVI) is an indicator related to the land cover obtained from satellite images as:

$$
\mathrm{NDVI}=\frac{\alpha \mathrm{p}_{(\mathrm{nir})}-\alpha \mathrm{p}_{(\mathrm{red})}}{\alpha \mathrm{p}_{(\mathrm{nir})}+\alpha \mathrm{p}_{(\mathrm{red})}}
$$

where $\alpha \mathrm{p}_{\text {nir }}$ and $\alpha \mathrm{p}_{\text {red }}$ represent the planetary albedo over the ranges of wavelengths in the near infrared (subscript nir) and red (subscript red) regions of the solar spectrum, which for the Landsat 8 satellite were B5 and B4, respectively.

The instantaneous values of the ratio of actual to reference evapotranspiration $\left(\mathrm{ET}_{\mathrm{r}}\right)$ were modelled ${ }^{7}$ :

$$
\mathrm{ET}_{\mathrm{r}}=\exp \left[\mathrm{a}_{\mathrm{S}}+\mathrm{b}_{\mathrm{S}}\left(\frac{\mathrm{T}_{0}}{\alpha_{0} \mathrm{NDVI}}\right)\right]
$$

where and $a_{s}$ and $b_{s}$ are the regression coefficients 1.0 and -0.008 for the northwestern São Paulo conditions, respectively ${ }^{21}$.

The $\mathrm{ET}_{\mathrm{r}}$ values besides being a soil moisture indicator, is also used to retrieve the ET daily values by multiplying it by ET0 daily grids ${ }^{4}$ :

$\mathrm{ET}=\mathrm{ET}_{\mathrm{r}} \mathrm{ET} 0$

Eq. 6 does not work for water bodies, i.e. when NDVI $<0$. Thus, the concept of equilibrium evapotranspiration $\left(\mathrm{ET}_{\mathrm{eq}}\right)^{22}$ is adopted under these conditions in the SAFER algorithm, and $\lambda \mathrm{E}_{\text {eq }}$ retrieved throughout conditional functions applied to the NDVI values and transformed in millimeters of water:

$\lambda \mathrm{E}_{\mathrm{eq}}=\frac{\mathrm{s}\left(\mathrm{R}_{\mathrm{n}}-\mathrm{G}\right)}{\mathrm{s}+\gamma}$

where $s$ is the slope of the curve relating saturation water vapor pressure to $T_{a}, G$ is the ground heat flux and $\gamma$ is the psychometric constant. Under these conditions, as the surface moisture availability is not constrained, water vapor transfer is only limited by the available energy.

Daily $R_{n}$ was calculated by using the Slob equation:

$$
\mathrm{R}_{\mathrm{n}}=\left(1-\alpha_{0}\right) \mathrm{RG}-\mathrm{a}_{\mathrm{L}} \tau_{\mathrm{sw}}
$$

where the regression coefficient $a_{L}$ was spatially distributed through its relationship with $\mathrm{T}_{\mathrm{a}}^{5}$.

$\mathrm{a}_{\mathrm{L}}=\mathrm{a}_{\mathrm{t}} \mathrm{T}_{\mathrm{a}}-\mathrm{b}_{\mathrm{t}}$

and $a_{t}$ and $b_{t}$ are regression coefficients 6.99 and 39.93 .

For the daily $\mathrm{G}$ values, the following equation was used:

$$
\frac{\mathrm{G}}{\mathrm{R}_{\mathrm{n}}}=\mathrm{a}_{\mathrm{G}} \exp \left(\mathrm{b}_{\mathrm{G}} \alpha_{0}\right)
$$


where $\mathrm{a}_{\mathrm{G}}$ and $\mathrm{b}_{\mathrm{G}}$ are regression coefficients found to be 3.98 and $-25.47^{6}$.

For Biomass estimation, the values of Absorbed Photosyntetically Active Radiation (APAR) can be approximated directly from $\mathrm{PAR}^{4,7}$ :

$$
\mathrm{APAR}=\left(\mathrm{a}_{\mathrm{p}} \mathrm{NDVI}+\mathrm{b}_{\mathrm{p}}\right) \mathrm{PAR}
$$

The coefficients $a_{p}$ and $b_{p}$ were 1.257 and -0.161 , respectively ${ }^{16}$.

BIO was then obtained according to Teixeira et al. ${ }^{4}$ :

$\mathrm{BIO}=\varepsilon_{\max } \frac{\mathrm{ET}}{\mathrm{ET} 0}$ APAR 0.864

where $\varepsilon_{\max }$ is the maximum light use efficiency, which was considered as $2.5 \mathrm{~g} \mathrm{MJ}^{-1}$ for the majority c4 species in the study area and 0.864 is a unit conversion factor?

The water productivity based on evapotranspiration ${ }^{7}$ was then acquired as:

$\mathrm{WP}=\frac{\mathrm{BIO}}{\mathrm{ET}}$

\section{RESULTS AND DISCUSSION}

\subsection{Weather conditions}

The weather-driving forces for ET and BIO are RG, precipitation (P), and the atmospheric demand represented by ET0. These parameters are presented in Fig. 2 on a decade time-scale inside the image acquisitions period from May/2013 to October/2014, with data from the agrometeorological station "Ilha Solteira" (see also Fig. 1).

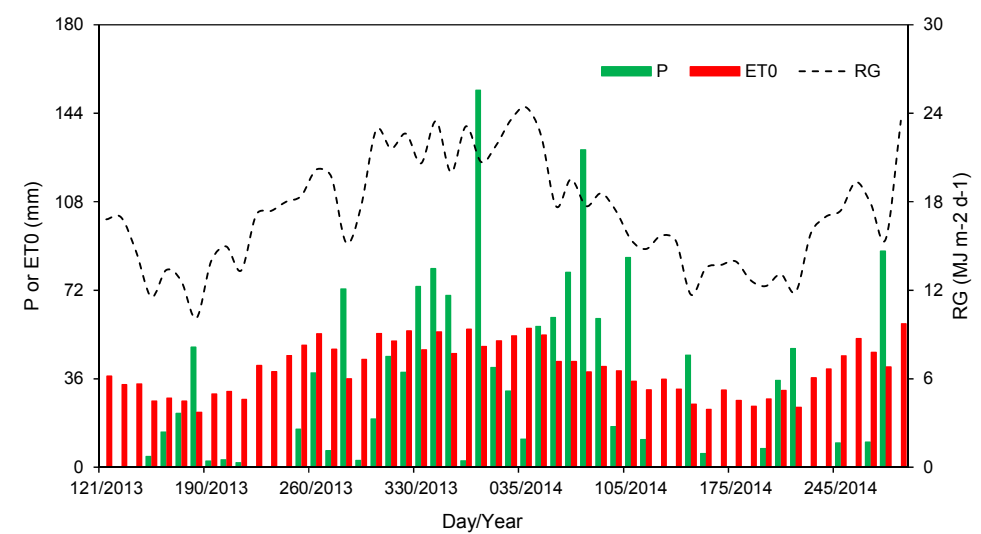

Figure 2. Decade values of the weather variables inside the image acquisitions period from May/2013 to October/2014, with data from the agrometeorological station "Ilha Solteira". Precipitation (P), reference evapotranspiration (ET0) and incident global solar radiation $(\mathrm{RG})$.

From the three weather parameters in Fig. 2, $\mathrm{P}$ was the most variable along the period of image acquisitions, with the highest values happening from the end of September (Day/Year 240/2013) to April (Day/Year 115/2014), with twodecade periods with precipitation above $120 \mathrm{~mm}$, between December 2013 and March 2014. Some short periods with no rainfall happened in August of 2013 (Day 210 to 240) and from June to August of 2014 (from day 155 to 185 and from day 215 to 235$)$.

Although with smaller amplitudes than P, the larger ET0 values occurred during the same periods of higher rainfall amounts, what is in favour for the ET and BIO rates. The smallest atmospheric demand, with the decade ET0 values 
bellow $30 \mathrm{~mm}$ were from the end of May (Day 140) to the end of July (Day 210) of both years, coinciding with some occasions of rainfall absence.

The trend of the incident global solar radiation (RG) followed that for ET0, as it is one of the input parameter for the atmospheric demand. The highest RG values with decade averages above $20 \mathrm{MJ} \mathrm{m}^{-2} \mathrm{~d}^{-1}$ were between the second half of October (Day/Year 290/2013) to the first half of February (Day/Year 045/2014). Satellite images processed under these conditions will present high both ET and BIO rates, as large RG levels, besides increasing water fluxes, intensify the photosynthetic activity.

\subsection{Large scale evapotranspiration}

Fig. 3 shows the spatial distribution of the evapotranspiration (ET) daily values for some of the image acquisitions days with different thermohydrological conditions from May/2013 to October/2014 in the agricultural growing areas of the northwestern side of São Paulo state, Southeast Brazil.

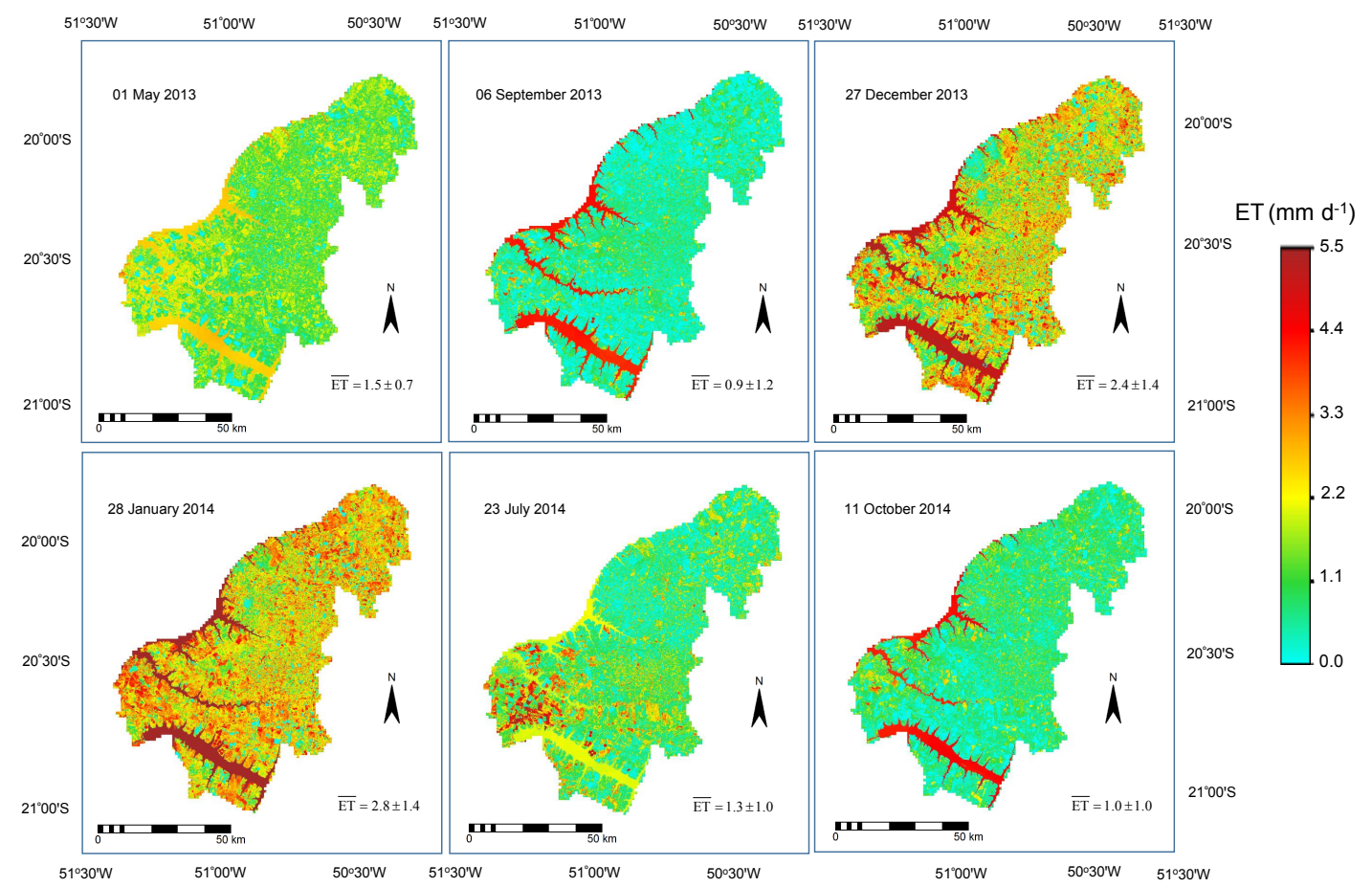

Figure 3. Spatial distribution of the evapotranspiration (ET) daily values for some of the image acquisitions days with different thermohydrological conditions from May/2013 to October/2014 in the agricultural growing areas of the northwestern side of São Paulo state, Southeast Brazil. The over bars means averages showed together with the standard deviations.

Considering all the agricultural growing regions inside the hydrological basins of Turvo/Grande, São José dos Dourados and Baixo Tietê, the spatial and temporal variation of ET is evident along the different thermohydrological conditions of the year. During the rainy period, the maximums were verified in January/2014. These large ET pixel values are related to high rainfall amounts together with large atmospheric demand, conditions that happened from the end of 2013 to the start of 2014.

The lowest ET rates represented by the image of 06 September 2013 (Day 249) in Fig. 3 occurred under water stress conditions, after a period with absence of rainfall and increasing solar radiation levels (see also Fig. 2). In this natural water deficit situation, irrigated crops and water bodies are highlighted from the other surface types. Stomata of natural species close under water stress conditions limiting transpiration and photosynthesis, and, in general, irrigation intervals are short, with a uniform water supply, reducing the heat losses to the atmosphere in irrigated plots. 
According to Fig. 3, the effect of the soil moisture in the magnitude of the ET rates is strong. Vegetation pixels with values lower than $1.0 \mathrm{~mm} \mathrm{~d}^{-1}$ occurred during periods with low rainfall amounts, representing natural species. The highest standard deviation value, above $2 \mathrm{~mm} \mathrm{~d}^{-1}$ occurred during the period of rain concentrations, as a consequence of the soil moisture heterogeneity. Considering a whole year, the annual average ET value for the mixture of agroecosystems was $559 \pm 365 \mathrm{~mm} \mathrm{yr}^{-1}$.

The daily average range in the current study are higher than those reported by Hernandez et al. ${ }^{23}$ for Pereira Barreto, in areas with predominance of sugar cane crop $\left(0.6 \pm 0.4\right.$ and $\left.1.8 \pm 0.9 \mathrm{~mm} \mathrm{~d}^{-1}\right)$. Our ET values were also higher than those found by Coaguila et $\mathrm{al}^{24}$ in the Mula sub basin $\left(0.4 \pm 0.5\right.$ to $\left.1.4 \pm 0.7 \mathrm{~mm} \mathrm{~d}^{-1}\right)$. As both last studies were in our study region, our larger values could be explained by the size of the areas involving more agro-ecosystems types.

\subsection{Large scale biomass production}

Fig. 4 shows the spatial distribution of the biomass production (BIO) daily values for some of the image acquisitions days with different thermohydrological conditions from May/2013 to October/2014 in the agricultural growing areas of the northwestern side of São Paulo state, Southeast Brazil.



Figure 4. Spatial distribution of the biomass production (BIO) daily values for some of the image acquisitions days with different thermohydrological conditions from May/2013 to October/2014 in the agricultural growing areas of the northwestern side of São Paulo state, Southeast Brazil. The over bars means averages showed together with the standard deviations.

As there is a relation between $\mathrm{BIO}$ and $\mathrm{ET}$, similar trend for $\mathrm{BIO}$ values are evident along the year. The photosyntetically active radiation (PAR) being around $44 \%$ of $\mathrm{RG}^{7}$, is very high, and with the water availability, this radiation is very well intercepted by the crop leaves for photosynthesis. With high levels of PAR, natural vegetation produce large amounts of $\mathrm{BIO}$ during the rainy periods, while outside these conditions there is a strong contrast with irrigated crops.

Considering the study region as a whole, the spatial and temporal variation of BIO along the year is evident, mainly when observing the images of 28 January 2014 inside the wettest period with that for 06 September 2013, under the 
natural driest conditions. Rainfalls from the end of 2013 to the start of 2014 provided much water storage in the root zones of the natural species, keeping this ecosystem wet and green, while during the driest periods, irrigated crops produce large $\mathrm{BIO}$, as the soils are moist during the irrigation periods in absence or with little amount of rainfall. Outside the rainy periods, irrigated crops are very well highlighted from the natural vegetation.

The conjugated effect of increasing soil moisture and solar radiation contributes to an increment in the BIO regional values from the end of 2013 to the start of 2014. The highest standard deviation occurred in January/2014, reaching to above $50 \mathrm{~kg} \mathrm{ha}^{-1} \mathrm{~d}^{-1}$, when there was the largest heterogeneity of BIO among the agro-ecosystems during the year. Considering the whole year, the BIO averaged value for mixture of agro-ecosystems was $13.2 \pm 10.7 \mathrm{tha}^{-1} \mathrm{y}^{-1}$.

The BIO daily average values of the current are lower than those reported by Hernandez et al. for Pereira Barreto, in areas with predominant sugar cane crop $\left(18 \pm 15\right.$ and $\left.92 \pm 51 \mathrm{~kg} \mathrm{ha}^{-1} \mathrm{~d}^{-1}\right)$. However, higher than those found by Coaguila et al. ${ }^{24}$ in the Mula sub basin $\left(9 \pm 15\right.$ to $\left.52 \pm 30 \mathrm{~kg} \mathrm{ha}^{-1} \mathrm{~d}^{-1}\right)$. As both researches were in same our study region, different results could be explained by the size of the areas with distinct agro-ecosystems involved.

\subsection{Water productivity assessments}

Fig. 5 shows the spatial distribution of the water productivity (WP) daily values for some of the image acquisitions days with different thermohydrological conditions from May/2013 to October/2014 in the agricultural growing areas of the northwestern side of São Paulo state, Southeast Brazil.

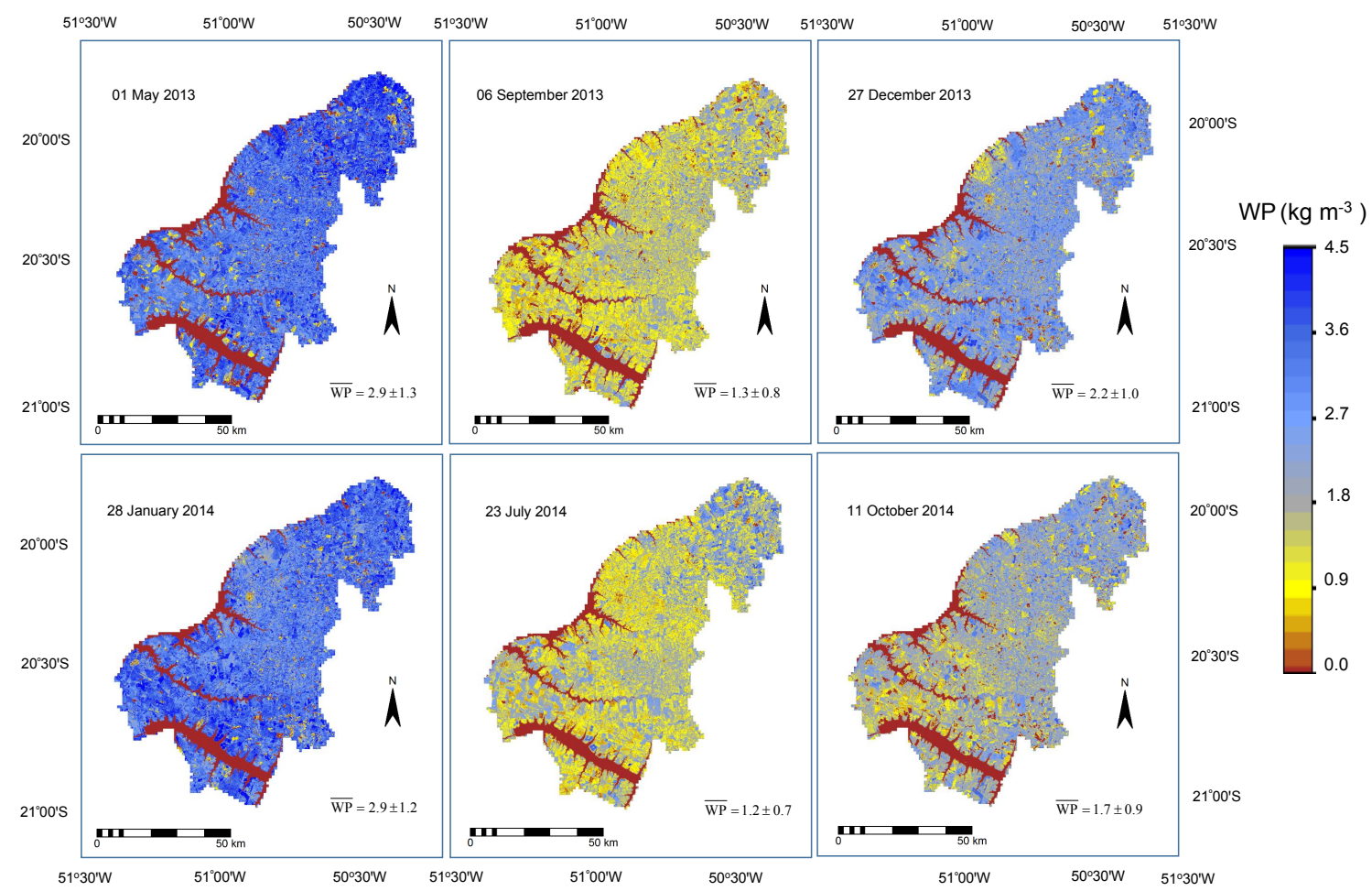

Figure 5. Spatial distribution of the water productivity (WP) daily values for some of the image acquisitions days with different thermohydrological conditions from May/2013 to October/2014 in the agricultural growing areas of the northwestern side of São Paulo state, Southeast Brazil. The over bars means averages showed together with the standard deviations.

The maximum WP values occurred in two periods of the year. One during the rainy conditions in December/2014, but another one with absence of rains, in May/2013. In both periods, some areas reached to values close to $4.5 \mathrm{~kg} \mathrm{~m}^{-3}$, 
involving irrigation areas and natural vegetation. The lower ET in May/2013 compensate the lower BIO, increasing WP to similar values of those with high ET and BIO rates of January/2014.

The smallest WP values occurred in 23 July 2014, because of low BIO and intermediary ET rates. Considering the whole year, the WP averaged value for the mixture of agro-ecosystems was $1.0 \pm 1.1 \mathrm{~kg} \mathrm{~m}^{-3}$. Maximum values around $2.1 \mathrm{~kg} \mathrm{~m}^{-3}$ are for irrigated crops, which multiplying by the harvest index it is possible to estimate the crop water productivity.

The WP values of the current study are lower than those reported by Hernandez et al. ${ }^{23}$ for Pereira Barreto, in areas with predominance of sugar cane crop $\left(2.2 \pm 0.9\right.$ and $\left.3.9 \pm 1.4 \mathrm{~kg} \mathrm{~m}^{-3}\right)$. Also, lower than those found by Coaguila et al. ${ }^{24}$ in the Mula sub basin $\left(1.7 \pm 0.8\right.$ to $\left.3.4 \pm 1.8 \mathrm{~kg} \mathrm{~m}^{-3}\right)$. As both studies were done in our study region, different results could be explained by the size of the areas and distinct agro-ecosystems involved presented different ET and BIO rates.

Table 1 presents the average daily values and standard deviations of the modelling biophysical parameters involved in water productivity assessments, for the period of May/2013 to October/2014 in the growing agricultural areas of the northwestern São Paulo state, Southeast Brazil.

Table 1. Average daily values and standard deviations of the modelling biophysical parameters for the period of May/2013 to October/2014 in the growing agricultural areas of the northwestern São Paulo state, Southeast Brazil: surface albedo $\left(\alpha_{0}\right)$; Normalized Difference Vegetation Index (NDVI); surface temperature $\left(\mathrm{T}_{0}\right)$ actual evapotranspiration (ET); Biomass production (BIO); and water productivity (WP) based on ET.

\begin{tabular}{|c|c|c|c|c|c|c|}
\hline $\begin{array}{c}\text { Parameter/ } \\
\text { Municipality }\end{array}$ & $\begin{array}{l}\alpha_{0} \\
(-)\end{array}$ & $\begin{array}{l}\text { NDVI } \\
(-)\end{array}$ & $\begin{array}{c}\mathbf{T}_{0} \\
(\mathbf{K})\end{array}$ & $\begin{array}{c}\text { ET } \\
\left(\mathbf{m m ~ d}^{-1}\right)\end{array}$ & $\begin{array}{c}\text { BIO } \\
\left(\mathrm{kg} \mathrm{ha}^{-1} \mathrm{~d}^{-1}\right)\end{array}$ & $\begin{array}{c}\text { WP } \\
\left(\mathrm{Kg} \mathrm{m}^{-3}\right)\end{array}$ \\
\hline Paranapuã (TG) & $0.18 \pm 0.01$ & $0.52 \pm 0.12$ & $301.9 \pm 1.4$ & $1.5 \pm 0.8$ & $46 \pm 30$ & $2.6 \pm 0.8$ \\
\hline Populina (TG) & $0.18 \pm 0.01$ & $0.53 \pm 0.12$ & $301.9 \pm 1.5$ & $1.4 \pm 0.7$ & $44 \pm 28$ & $2.6 \pm 0.8$ \\
\hline Santa Rita d'Oeste (TG) & $0.19 \pm 0.01$ & $0.51 \pm 0.11$ & $302.3 \pm 1.4$ & $1.4 \pm 0.7$ & $42 \pm 28$ & $2.4 \pm 0.7$ \\
\hline Rubinéia (SJD) & $0.19 \pm 0.01$ & $0.50 \pm 0.11$ & $302.4 \pm 1.4$ & $1.4 \pm 0.7$ & $40 \pm 26$ & $2.2 \pm 0.6$ \\
\hline Santa Fé do Sul (SJD) & $0.18 \pm 0.01$ & $0.50 \pm 0.11$ & $302.3 \pm 1.3$ & $1.4 \pm 0.7$ & $41 \pm 28$ & $2.3 \pm 0.7$ \\
\hline Suzanápolis (SJD) & $0.18 \pm 0.01$ & $0.51 \pm 0.11$ & $301.9 \pm 1.6$ & $1.5 \pm 0.8$ & $43 \pm 29$ & $2.3 \pm 0.7$ \\
\hline Ilha Solteira (SJD) & $0.19 \pm 0.03$ & $0.51 \pm 0.12$ & $302.0 \pm 1.7$ & $1.7 \pm 0.9$ & $47 \pm 31$ & $2.2 \pm 0.7$ \\
\hline Pereira Barreto (BT) & $0.19 \pm 0.01$ & $0.50 \pm 0.12$ & $302.0 \pm 1.8$ & $1.4 \pm 0.9$ & $41 \pm 30$ & $2.2 \pm 0.7$ \\
\hline Sud Mennucci (BT) & $0.19 \pm 0.01$ & $0.50 \pm 0.11$ & $302.0 \pm 1.5$ & $1.3 \pm 0.7$ & $40 \pm 27$ & $2.3 \pm 0.7$ \\
\hline Mean & $0.18 \pm 0.01$ & $0.51 \pm 0.11$ & $302.1 \pm 1.5$ & $1.4 \pm 0.8$ & $43 \pm 29$ & $2.3 \pm 0.7$ \\
\hline
\end{tabular}

* TG, SJD and BT means the hydrological basins Turvo/Grande, São José dos Dourados and Baixo Tietê.

The highlighted agricultural growing areas are Paranapuã (PA), Populina (PO) and Santa Rita d'Oeste (SRO) in the Turvo/Grande (TG) basin; Rubinéia (RB), Santa Fé do Sul (SFS) and Suzanópolis (SZ) and Ilha Solteira (IS), in the São José dos Dourados (SJD) basin; and Pereira Barreto (PB) and Sud Mennucci (SM), in the Baixo Tietê (BT) basin (see Fig. 1).

For the remote sensing parameters, $\alpha_{0}$, NDVI and $\mathrm{T}_{0}$, there were some differences among the agricultural growing areas. Highlights for $\alpha_{0}$ average values are to Ilha Solteira in the SJD basin, with the high end of 0.22 while the low end of 0.17 happened in this basin but also in the TG basin. The range for NDVI mean values were from 0.38 in Pereira Barreto inside the BT basin to 0.65 in Populina (TG). The average $\mathrm{T}_{0}$ presented also some differences between the agricultural growing areas, ranging between $300.2 \mathrm{~K}$ in Pereira Barreto (BT) to 303.8 in Rubnéia (SJD). The distinctions among the remote sensing parameters, together with distinct weather conditions will promote different ET and BIO rates, which in turn affect WP.

The highest averages for both ET $\left(1.7 \pm 0.9 \mathrm{~mm} \mathrm{~d}^{-1}\right)$ and BIO $\left(47 \pm 31 \mathrm{~kg} \mathrm{ha}^{-1} \mathrm{~d}^{-1}\right)$ were for Ilha Solteira (SJD), while the lowest rates happened in Sud Mennucci, between $1.3 \pm 0.7 \mathrm{~mm} \mathrm{~d}^{-1}$ and $40 \pm 27$ (BT). These ranges give WP varying from $2.2 \pm 0.6$ to $2.6 \pm 0.8 \mathrm{~kg} \mathrm{~m}^{-3}$, with the highest end happening in the TG hydrological basin. Considering the annual time-scale, irrigated agricultural crops will consume around 770, 828 and $786 \mathrm{~mm} \mathrm{yr}^{-1}$ with BIO of 27,26 and 25 $\mathrm{t} \mathrm{ha}^{-1} \mathrm{yr}^{-1}$, respectively in TG, SJD and BT hydrological basins. Thus, increments in irrigated areas should be stimulated in the northwestern side of the state, mainly in the first basin, to return good yield with less water use. 


\section{CONCLUSIONS}

Coupling remote sensing parameters from Landsat 8 satellite images and weather data from agrometeorological stations allowed the water productivity assessments on a large scale along the period from May/2013 to October/2014 in a mixture of agro-ecosystems of the agricultural growing areas inside the northwestern side of São Paulo state, Brazil. These assessments may subsidize a better understanding of the dynamic of the biophysical parameters, contributing to the sustainability of the rational agro-ecosystems exploration in the future, avoiding water scarcity in the near future. It could be concluded that increments of agricultural irrigated areas should be stimulated in the northwestern side of the state, mainly in the Turvo/Grand hydrological basin, to retrieve good yield with less water use.

\section{ACKNOWLEDGEMENTS}

The National Council for Scientific and Technological Development (CNPq) is acknowledged for the financial support to a project on Large-scale Water Productivity in Brazil.

\section{REFERENCES}

[1] Hernandez. F.B.T., Souza. S.A.V. de, Zocoler. J.L. and Frizzone. J.A., "Simulação e efeito de veranicos em culturas desenvolvidas na região de Palmeira d'Oeste. Estado de São Paulo, " Eng. Agríc. 23, 21-30 (2013).

[2] Miralles, D.G., Holmes, T.R.H., De Jeu, R.A.M., Gash, J.H.,Meesters, A.G.C.A. and Dolman, A.J. "Global landsurface evaporation estimated from satellite-based observations, " Hydrol. Earth Syst. Sci. 15, p. 453-469 (2011).

[3] Pôças, I., Cunha, M., Pereira, L.S. and Allen, R.G. "Using remote sensing energy balance and evapotranspiration to characterize montane landscape vegetation with focus on grass and pasture lands," Int. J. App. Earth Obs. Geoinf. 21, 159-172 (2013).

[4] Teixeira, A.H. de C., Leivas, J.F., Ronquim, C.C. and Victoria, D. de C., "Sugarcane water productivity assessments in the São Paulo state, Brazil," Int. J. Remote Sens. Applic. 6, 84-95 (2016).

[5] Teixeira, A. H. de C., Bastiaanssen, W. G. M., Ahmad, M-ud-D, Bos, M. G. and Moura, M. S. B., "Analysis of energy fluxes and vegetation-atmosphere parameters in irrigated and natural ecosystems of semi-arid Brazil," J. Hydrol. 362, 110-127 (2008).

[6] Teixeira, A.H. de C., "Determining regional actual evapotranspiration of irrigated and natural vegetation in the São Francisco river basin (Brazil) using remote sensing an Penman-Monteith equation," Remote Sens. 2, 1287-1319 (2010)

[7] Teixeira, A.H. de C. Hernandez, F.B.T., Warren, M.S., Andrade, R.G., Victoria, D. de C., Bolfe, E.L., Thenkabail, P.S. and Franco, R.A.M. Water Productivity Studies from Earth Observation Data: Characterization, Modeling, and Mapping Water Use and Water Productivity. In: Prasad, S.T. (Org). [Remote Sensing of Water Resources, Disasters, and Urban Studies.] 1ed.Boca Raton, Florida: Taylor and Francis, v. III, 101-126. (2015a).

[8] Wu, C., Munger, J.W., Niu, Z., and Kuanga, D. "Comparison of multiple models for estimating gross primary production using MODIS and eddy covariance data in Havard Forest, " Remote Sens. Environ. 114, 2925-2939 (2010).

[9] De Silva, A.L.C., and De Costa, W.A.J.M. "Growth and radiation use efficiency of sugarcane under irrigated and rain-fed conditions in Sri Lanka," Sugar Tech 14, 247-254 (2012).

[10] Adak, T.; Kumar, G.; Chakravarty, N.V.K.; Katiyar, RK, and Deshmukh, P.S. "Biomass and biomass water use efficiency in oilseed crop (Brassica Jnceae L.) under semi- arid microenvironments, " Biom. Bioen. 51, 154-162 (2013).

[11] Monteith, J.L., "Solar radiation and productivity in tropical ecosystems," J. App. Ecol. 9, 747-766 (1972).

[12] Tesfaye, K., Walker, S. and Tsubo, M.. "Radiation interception and radiation use efficiency of three grain legumes under deficit conditions in a semi-arid environment," Europ. J. Agron. 25, 60-70 (2006).

[13] van Heerden, P.D.R., Donaldson, R.A., Watt, D.A., and Singels, A., "Biomass accumulation in sugarcane: unravelling the factors underpinning reduced growth phenomena," J. .Exp. Bot. 61, 2877-2887 (2010).

[14] Baccine, A., Friedl, M. A., Woodcrock, C. E. and Warbington. R., "Forest biomass estimation over regional scales using multisource data," Geophys. Res. Lett. 31, 1-4, (2004).

[15] Shi, X., Elmore, A., Li, X., Gorence, N. J., Jin, H. and Zhang, X., "Using Spatial Information Technologies to Select Sites for Biomass Power Plants: A Case Study in Guangdong, China," Biom. Bioen. 32, 35-43 (2008). 
[16] Bastiaanssen, W.G.M., Ali, S. "A new crop yield forecasting model based on satellite measurements applied across the Indus Basin, Pakistan,"Agric., Eco.Environ. 94 (3), 32-340 (2003).

[17] Vanhellemont, Q. and Kevin Ruddick, K., "Turbid wakes associated with offshore wind turbines observed with Landsat 8," Remote Sens. Env., 145, 105-115 (2014).

[18] Santos. G.O., Hernandez. F.B.T., Rossetti. J.C., "Balanço hídrico como ferramenta ao planejamento agropecuário para a região de Marinópolis, nor oeste do Estado de São Paulo," Rev. Bras. Agric. Irrig. 4, 142-149 (2010).

[19] Allen, R. G., Pereira, L. S., Raes, D. and Smith, M., Crop Evapotranspiration: Guidelines for Computing Crop Water Requirements; Food and Agriculture Organization of the United Nations: Rome, Italy (1998).

[20] Teixeira, A.H. de C., Leivas, J.F., Hernandez, F.B.T. and Franco, R.A.M., "Modelling radiation and energy balances with Landsat 8 images under different thermohydrological conditions in the Brazilian semi-arid region," Proc. SPIE 9637, 1-14 (2015b).

[21] Hernandez, F.B.T., Neale, C.M.U., Teixeira, A.H. de C. and Taghvaeian, S., "Determining Large Scale Actual Evapotranspiration Using Agro-Meteorological and remote sensing data in the Northewest of São Paulo state, Brazil," Acta Hort. 1038, 263-270 (2014).

[22] Raupasch, M.R., "Combination theory and equilibrium evaporation," Q. J. Roy. Meteor. Soc. 127, 1149-1181 (2001).

[23] Hernandez, F.B.T., Franco, R.A.M. and Teixeira, A.H. de C., "Uso do satélite Landsat 8 na determinação da produtividade da água em bacia hidrográfica com predomínio do uso agrícola da cana-de-açúcar," Simp. Bras. Sens. Rem. 3229-3236 (2015).

[24] Coaguila, D., Hernandez, F.B.T. and Teixeira, A.H. de C., "Estacionalidade da evapotranspiração e produtividade da água na microbacia do Córrego da Mula em Santa Fé do Sul - SP," Rev. Bras. Agric. Irrig. 9, 232-238 (2015). 